\title{
INDONESIAN FARMERS CAN CONTRIBUTE IN REDUCING GREENHOUSE GASES EMISSION FROM WETLAND RICE FIELD
}

\author{
Iswandi Anas ${ }^{1,2}$, Nia K. Megasari' ${ }^{1}$, Suprihati ${ }^{3}$ and Hiroyuki OHTA ${ }^{2}$
}

\author{
${ }^{1}$ Laboratory of Soil Biotechnology, Bogor Agricultural University (IPB), Bogor, Indonesia \\ 2Institute for Global Change Adaptation Science (ICAS), Ibaraki University, Japan \\ 3UKSW (Christian University Satya Wacana), Salatiga, Central Java, Indonesia
}

\begin{abstract}
Agricultural sector contribute significantly to the total GHG emission. There are some GHG mitigation options available but so far non of these mitigation options is being implemented by farmers. There is no real action have been taken by government to encourage farmers to implement the available mitigation option to reduce GHG emission from wetland rice field. We discuss some mitigation options and we suggest two additional GHG mitigation options namely crops rotation and System of Rice Intensification (SRI) that probably more attractive to farmer to implement them. However the impacts of these two proposed options as GHG mitigation options should be studied further.
\end{abstract}

Key words: Greenhouse gases (GHG), mitigation option, farmer contribution, SRI, crop rotation

\section{INTRODUCTION}

According to the UN Secretary General, Ban Kimoon, world leaders have demonstrated their political will to make a breakthrough on climate change. He addressed his speech recently on the wrapping up the UNFCCC Meeting held in Bali Indonesia in last September 2007, attended by over 150 nations including 80 heads of State or Government. He added, technological solution for pushing forward the goal of adaptation and mitigation to global climate change already exist and global collaboration must be urgently needed to help the developing countries to reduce their GHG emission. This means every country should take a serious and real action(s) to implement the available GHG mitigation options to reduce their GHG emission.

Based on UNFCCC (2006) in some Asian countries, the highest GHG emission come from energy sector, followed by agriculture or industrial sectors and waste. However, looking at GHG emission from agricultural sector only, in Asian developed countries such as in Japan and Korea, GHG emission from agricultural sector is very low while in the developing countries, the percentage of GHG emission from agricultural sector is much higher. GHG emission from agricultural sector in China, India, Indonesia and Thailand have a significant contribution to the total GHG emission of each corresponding country. This also means that mitigation technology applied in the agricultural sector in these later mentioned countries might have a significant effect in the reduction of their total GHG emission.

Until now, in the agricultural sector in Indonesia, although there are some GHG mitigation options available but none of these mitigation options are being applied by farmer to reduce GHG emission from agricultural land. In relation to this, it is interesting to discuss the possible contribution of Indonesian farmers in reducing GHG emission when these mitigation options are adopted. Some possible obstacles and encouraging factors that might be faced in implementation of mitigation options are also interesting subjects to discuss. As we all know that GHG gases mainly consist of $\mathrm{CO}_{2}, \mathrm{CH}_{4}, \mathrm{~N}_{2} \mathrm{O}$ and $\mathrm{NO}$ but due to the lack of data available particularly in the developing countries, only one or two of these gases, mainly $\mathrm{CH}_{4}$ and $\mathrm{N}_{2} \mathrm{O}$ are discussed.

\section{GHG EMISSION FROM AGRICULTURAL SECTOR}

According to UNFCCC Report (2006), GHG emission from agricultural sector in developing Asian countries is higher than GHG emission from agricultural sector in the developed Asian countries such as Japan and Korea (Figure 1). In Japan, the GHG emission from agricultural sector was only $2 \%$ of the total GHG emission while in Korea, it was only $4 \%$ of the total GHG emission. The percentage of GHG emission from agricultural sector in developing countries was $15 \%$ in China, $26 \%$ in Indonesia, $28 \%$ in India and $35 \%$ in Thailand. The total amount of GHG emission from each country was China (4.058 Mt $\mathrm{CO}_{2}$, Japan (1.355 $\left.\mathrm{Mt} \mathrm{CO}_{2}\right)$, India (1.214 $\left.\mathrm{Mt} \mathrm{CO}_{2}\right)$ Indonesia (323 $\mathrm{Mt} \mathrm{CO}_{2}$ ), Korea (299 $\mathrm{Mt} \mathrm{CO}_{2}$ ) and Thailand (224 $\mathrm{Mt} \mathrm{CO}_{2}$ ). GHG emission from agricultural sector in China, India, Indonesia and Thailand occupied a high portion of the total GHG emission. This means that mitigation options applied in the agricultural sector might have a significant effect in reduction of the total GHG emission from these countries. 


\section{GHG INVENTORIES IN SOME ASIAN COUNTRIES}
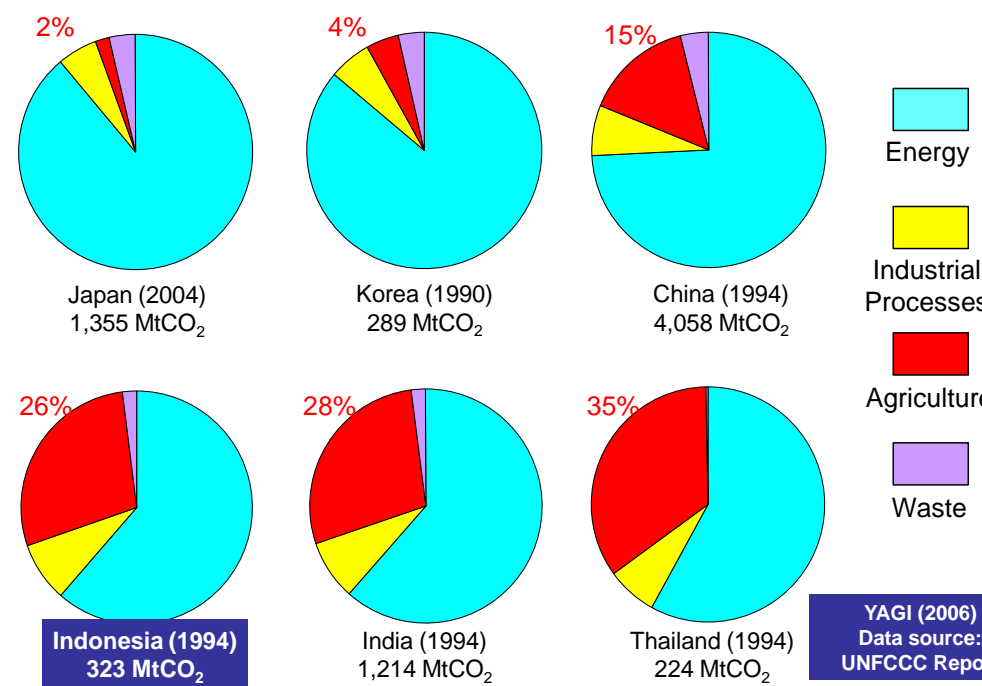

Figure 1. GHG Inventories in some Asian Countries (UNFCCC Report 2006, modified by Yagi, 2006)

The distribution of GHG emission from agricultural sector in Japan and Korea is presented in Table 1. Rice field is one of the most important source of GHG emission from agricultural sector. In Japan, as high as $30.0 \%$ of GHG emission from the agricultural sector come from rice cultivation while in Korea, GHG emission from rice cultivation even higher, as high as $44.9 \%$ of the GHG emission from agricultural sector. However, as it has been stated earlier, the GHG emission from agricultural sector in both countries was only 2\% (Japan) and 4\% (Korea) of the total GHG emission in each country. There is no data available about the contribution of the rice field on GHG emission from agricultural sector in other Asian countries such as Indonesia, China, Thailand and India. However, it is more likely that the percentage of GHG emission from rice field is also high in these countries.

Table 1. Greenhouse Gas (GHG) Emission from Agricultural Sector in Japan and Korea

\begin{tabular}{lcccc}
\hline Country & \multicolumn{3}{c}{ Source of GHG from agricultural sector (\%) } \\
\hline & $\begin{array}{c}\text { Rice } \\
\text { cultivation }\end{array}$ & $\begin{array}{c}\text { Other } \\
\text { Agricultural } \\
\text { soils }\end{array}$ & $\begin{array}{c}\text { Manure } \\
\text { management }\end{array}$ & $\begin{array}{c}\text { Enteric } \\
\text { fermentation/ } \\
\text { Other }\end{array}$ \\
\hline Japan $^{1}$ & 30.0 & - & 38.0 & 16.3 \\
Korea $^{2}$ & 44.9 & 21.1 & 17.7 & $1{ }^{2}$ Shin and Lee \\
${ }^{1}$ Inubushi & and Yagi & (2006) only for methane; & \\
$(2006)$. & & & &
\end{tabular}

The reason is majority of rice field ecosystem in these countries is flooded rice ecosystem while in Japan and Korea, the majority of rice ecosystem is irrigated rice ecosystem (Wassmann, 2006). China, India and Indonesia are claimed as the main methane emitting countries I the world (Shearer and Khalil, 2000). China was reported to produce as much as $20 \mathrm{Tg}$ of methane per year from rice cultivation. This was rather overestimated since in the last report, China emitted only $8 \mathrm{Tg}$ methane per year. In Indonesia, flooded or wetland rice ecosystem is also considered to be the main source of methane in agricultural sector. In 2005, with the harvested area of wet land rice field in Indonesia 11.8 millions hectares (Table 2), methane emission was reported to reach $6.2 \mathrm{Tg}$ per year (Husin et al, 1994).

Table 2. Rice Harvested Area and Rice Production in Indonesia (BPS, 2007)

\begin{tabular}{ccccc}
\hline Year & $\begin{array}{c}\text { Rice } \\
\text { harvested } \\
\text { area (ha) }\end{array}$ & $\begin{array}{c}\text { Yield } \\
\text { Rate } \\
\text { (ton/ha) }\end{array}$ & $\begin{array}{c}\text { Total rice } \\
\text { production } \\
\text { (ton) }\end{array}$ & $\begin{array}{c}\text { Production } \\
\text { growth } \\
(\%)\end{array}$ \\
\hline 2002 & $11,521,166$ & 4.469 & $51,489,694$ & 2.04 \\
2003 & $11,488,034$ & 4.538 & $52,137,604$ & 1.26 \\
2004 & $11,922,974$ & 4.536 & $54,088,468$ & 3.74 \\
2005 & $11,839,060$ & 4.574 & $54,15,097$ & 0.12 \\
2006 & $11,786,430$ & 4.620 & $54,454,937$ & 0.56 \\
$2007 *$ & $11,757,845$ & 4.689 & $55,127,430$ & 1.23 \\
\hline
\end{tabular}

$*=$ Second forecast

However, other scientists reported that the methane emission from rice cultivation in Indonesia was only 3.7 Tg per year (Matthew et al, 1991) and more lower figure was reported by Bachelet and Neue (1993), i.e. 3.5 Tg methane per year. It was calculated that the methane emission from rice field in Indonesia was about 5.2 $\mathrm{Tg}$. As additional information, according to Duxbury and Mosier (1997) global methane emission from agriculture sector was about 205 - $245 \mathrm{Tg}$ methane per year. However, it is important to note that rice field ecosystem may act as source as well as sink of methane as reported by many authors (Rath et al., 1999; Wang and Adachi, 1999; Wang et al., 1999; Kumaraswamy et al., 2000; Wassmann and Aulakh, 2000; Inubushi et al., 2002). The magnitude of methane as well as $\mathrm{N}_{2} \mathrm{O}$ emitted from rice field ecosystem depend on the agricultural practices applied on a particular soil. 


\section{GHG EMITTED FROM WETLAND RICE FIELD CULTIVATED WITH OTHER CROPS}

In some parts of Indonesia, in good irrigation water management or in the area where irrigation water insufficient, wetland rice field (sawah) is cultivated with upland crops such as maize, soybean, peanut and other tuberous crops such taro or vegetable crops. Cultivating wetland rice field with other crops, reduce GHG emission from this soil or this soil might become a sink of GHG instead of source. To study this, we set up a series of experiments in $2005-2006$ in Bogor, West Java, Indonesia. The farmers' wetland rice field cultivated with different crops according to the farmer' cultivation practices obtained in very small area (1-2 ha) were used to take GHG samples. This very limited sampling area was meant to keep the soil characteristics and the microclimate of the area of study were similar. In this study we limited GHG emission only to methane emission. The results of methane emission from three wetland rice field location were presented in the Table 3. These data showed that wetland rice field cultivated with rice in three location constantly emitted methane gas much higher than wetland rice field cultivated with upland crops. Moreover, it was also observed in these three experimental locations that when wetland rice field cultivated with a certain upland crop, the land became a sink of methane gas instead of source. This is really interesting phenomenon.

To ensure the results of the first experiment, the methane gas emission from the same site in Cihideung Ilir and Marga Jaya was monitored in the second cropping season. Data in Table 4 showed that when wetland rice field in the first growing season planted with upland crops taro or mixed vegetable crops (Marga Jaya location), methane emission was only $-0.92 \pm 0.02 \mathrm{~g} \mathrm{CH}_{4} \mathrm{~m}^{-2}$ and -0.03 $\pm 0.11 \mathrm{~g} \mathrm{CH}_{4} \mathrm{~m}^{-2}$, respectively. However, when in the second growing season, these crops were replaced by wetland rice, methane emission jumped out very significantly to $75.47 \pm 100.02 \mathrm{~g} \mathrm{CH}_{4} \mathrm{~m}^{-2}$ and $38.60 \pm$ $10.39 \mathrm{~g} \mathrm{CH}_{4} \mathrm{~m}^{-2}$ respectively.

Table 3. Methane Emission from Wetland Rice Field Cultivated with Other Upland Crops (Suprihati, 2007; Iswandi et al., 2007)

\begin{tabular}{|c|c|c|c|}
\hline & Location & Crop & $\begin{array}{l}\text { Total methane emission } \\
\qquad\left(\mathrm{g} \mathrm{CH}_{4} \mathrm{~m}^{-2}\right)\end{array}$ \\
\hline \multirow[t]{5}{*}{1.} & Cihideung Ilir* & Wetland rice & $15.93 \pm 1.81$ \\
\hline & & Maize & $0.21 \pm 0.09$ \\
\hline & & Vegetable & $0.06 \pm 0.06$ \\
\hline & & Sweet potato & $2.00 \pm 1.63$ \\
\hline & & Yam bean & $-1.19 \pm 1.47$ \\
\hline \multirow[t]{5}{*}{2.} & Marga Jaya* & Wetland rice & $4.94 \pm 3.15$ \\
\hline & & Taro & $-0.92 \pm 0.02$ \\
\hline & & Long bean & $0.16 \pm 0.10$ \\
\hline & & Sweet potato & $0.21 \pm 0.01$ \\
\hline & & Mixed crops & $-0.03 \pm 0.11$ \\
\hline \multirow[t]{5}{*}{3.} & Pasar Rebo*** & Wetland rice & $7.50 \pm 0.53$ \\
\hline & & Vegetable & $0.46 \pm 0.53$ \\
\hline & & Sweet potato & $-0.77 \pm 0.64$ \\
\hline & & Yam bean & $-0.39 \pm 0.51$ \\
\hline & & Maize & $0.16 \pm 0.18$ \\
\hline
\end{tabular}

Table 4. Methane Emission from Wetland Rice Field Cultivated with Other Upland Crops for Two Consecutive Growing Seasons (Iswandi et al., 2007)

\begin{tabular}{|c|c|c|c|c|}
\hline Location & $\begin{array}{c}\text { First } \\
\text { growing } \\
\text { season }\end{array}$ & $\begin{array}{c}\text { Methane } \\
\text { emission } \\
\left(\mathrm{g} \mathrm{CH}_{4} \mathrm{~m}^{-2}\right)\end{array}$ & $\begin{array}{l}\text { Second } \\
\text { growing } \\
\text { season }\end{array}$ & $\begin{array}{c}\text { Methane } \\
\text { emission } \\
\left(\mathrm{g} \mathrm{CH}_{4} \mathrm{~m}^{-2}\right)\end{array}$ \\
\hline \multirow[t]{5}{*}{$\begin{array}{l}\text { Cihideung } \\
\text { Ilir }\end{array}$} & $\begin{array}{l}\text { Wetland } \\
\text { rice }\end{array}$ & $15.93 \pm 1.81$ & No crop & \pm \\
\hline & Maize & $0.21 \pm 0.09$ & Peanut & $0.29 \pm 0.15$ \\
\hline & Vegetable & $0.06 \pm 0.06$ & $\begin{array}{l}\text { Sweet } \\
\text { potato }\end{array}$ & $-1.6 \pm 1.48$ \\
\hline & $\begin{array}{l}\text { Sweet } \\
\text { potato }\end{array}$ & $2.00 \pm 1.63$ & No crop & \pm \\
\hline & Yam bean & $-1.19 \pm 1.47$ & $\begin{array}{l}\text { Sweet } \\
\text { potato }\end{array}$ & $0.33 \pm 0.53$ \\
\hline \multirow[t]{5}{*}{$\begin{array}{l}\text { Marga } \\
\text { Jaya }\end{array}$} & $\begin{array}{l}\text { Wetland } \\
\text { rice }\end{array}$ & $4.94 \pm 3.15$ & No crop & \pm \\
\hline & Taro & $-0.92 \pm 0.02$ & $\begin{array}{l}\text { Wetland } \\
\text { rice }\end{array}$ & $\begin{array}{l}75.47 \pm \\
100.02\end{array}$ \\
\hline & Long bean & $0.16 \pm 0.10$ & Vegetable & $0.55 \pm 0.34$ \\
\hline & $\begin{array}{l}\text { Sweet } \\
\text { potato }\end{array}$ & $0.21 \pm 0.01$ & $\begin{array}{l}\text { Sweet } \\
\text { potato }\end{array}$ & $-0.02 \pm 0.14$ \\
\hline & Mixed crops & $-0.03 \pm 0.11$ & $\begin{array}{l}\text { Wetland } \\
\text { rice }\end{array}$ & $\begin{array}{c}38.60 \pm \\
10.39\end{array}$ \\
\hline
\end{tabular}

It is important to note that in the second growing season where wetland rice field at Cihideung Ilir location was planted with sweet potato, as high as $-1.67 \mathrm{~g} \mathrm{CH}_{4} \mathrm{~m}^{-2}$ was absorb in this site. This means that as high as $16.7 \mathrm{~kg}$ $\mathrm{CH}_{4}$ was absorbed per hectare of wetland rice field. This was really interesting result obtained in this study.

\section{SOME OPTIONS OF GHG MITIGATION}

Some options of GHG mitigation from wetland rice field which have been investigated in some countries are presented in the Table 5. Irrigation water management, selection of rice cultivar, type, dosage and timing of fertilizer application, cultivation method, and organic matter application are among the mitigation options proposed by scientist to reduce GHG emission from wetland rice field.

These mitigation options were reported to be effective methods to reduce GHG emission from wetland rice field

However, the effectiveness of the GHG mitigation options varied considerably. Up to now, none of these option is being practiced by farmers widely. Adoption of the GHG mitigation options by farmer depend on many factors such as easiness of the option to be implemented, no additional cost or an extra work have to be done by farmer and no reduction in rice yield. Therefore we propose additional options of GHG mitigation, i.e. crop rotation in wetland rice field and System of Rice Intensification (SRI), a new introduced rice cultivation system which could be more attracted to farmer to implement these options. In the next sub-topic we elaborate these to additional GHG mitigation options. 
Table 5. Some Mitigation Options of GHG Emitted from Wetland Rice Field

\begin{tabular}{|c|c|c|}
\hline Option & Detail and GHG emission & Literature \\
\hline \multirow[t]{4}{*}{ Water management } & $\begin{array}{l}\text { Saturated irrigation water } 24.17 \% \text { less } \mathrm{CH}_{4} \text { emission than flooding but increase } \mathrm{N}_{2} \mathrm{O} \\
\text { by } 98.7 \% \text {, increased rice yield } 12 \%\end{array}$ & Suprihati (2007) \\
\hline & Mid season drainage reduce GHG emission & Wassmann, et al. (2000) \\
\hline & Intermittence irrigation water $30 \%$ less than flooding & Shin and Lee (2006) \\
\hline & $\begin{array}{l}\text { GHG emission with mid season drainage } 25.86 \%<\text { farmer practiced ; Multiple } \\
\text { drainage } 33.53 \%<\text { farmer practiced }\end{array}$ & Chidthaisong (2006) \\
\hline \multirow[t]{4}{*}{ Selection of rice cultivar } & $\begin{array}{l}\text { High-yielding cultivar with low MTC such as IR65598 and IR65600, economically } \\
\text { feasible, environmentally sound promising approach for methane mitigation }\end{array}$ & Aulakh et al. (2000) \\
\hline & $\begin{array}{l}\text { Rice with a few unproductive tiller, small root system, high root oxidative activity, } \\
\text { high harvest index ideal for mitigation GHG }\end{array}$ & Wang and Adachi (2000) \\
\hline & $\mathrm{CH}_{4}$ emission varied according to soil and rice variety & Singh et al. (1997) \\
\hline & $\begin{array}{l}\text { Selected cultivar emitted less } \mathrm{CH}_{4} \text { without reducing rice yield; IR64 better than } \\
\text { Membaramo, Way Opoburu and Cisadane }\end{array}$ & Setyanto et al. (2004) \\
\hline Fertilizer application & & Wassmann (2006) \\
\hline Cultivation method & direct seeding $55 \%$ less $\mathrm{CH} 4$ than transplanting & Shin and Lee (2006) \\
\hline \multirow[t]{2}{*}{ Organic matter } & $\begin{array}{l}\text { Not composted rice straw ( } 6 \text { ton): increase } 11.3 \% \mathrm{CH} 4 ; 51.2 \% \mathrm{~N} 2 \mathrm{O}, 8 \% \text { rice yield } \\
\text { increase }\end{array}$ & $\begin{array}{l}\text { Suprihati (2006); Iswandi et } \\
\text { al. (2007) }\end{array}$ \\
\hline & Composted rice straw $45 \%$ less $\mathrm{CH}_{4}$ emission & $\begin{array}{l}\text { Shin and Lee (2006); Yagi } \\
\text { (2006) }\end{array}$ \\
\hline Combination & $\begin{array}{l}\text { Saturated water treatment, rice straw application and urea application: increase rice } \\
\text { yield } 115 \% \text {, reduce } \mathrm{CH} 4 \text { by } 50 \%, \mathrm{~N} 2 \mathrm{O} \text { by } 77 \% \text { and GWP by } 50 \% \text {. }\end{array}$ & Suprihati, 2007 \\
\hline Crop rotation & $\begin{array}{l}\text { Wet land rice to upland crops reduce } \mathrm{CH}_{4} \text { emission very significantly (Proposed } \\
\text { mitigation option) }\end{array}$ & $\begin{array}{l}\text { Iswandi et al. (2007) (this } \\
\text { publication) }\end{array}$ \\
\hline $\begin{array}{l}\text { System of Rice Intensification } \\
\text { (SRI) }\end{array}$ & $\begin{array}{l}\text { Intermittence irrigation, less in organic fertilizer, young seedling, single seed, wider } \\
\text { space with and without organic matter amendment: } 78 \text { rice yield increase; } 20 \% \text { less } \\
\text { input; } 40 \% \text { less water; } 50 \% \text { less inorganic fertilizers (Proposed mitigation option) }\end{array}$ & $\begin{array}{l}\text { Iswandi et al. (2007) (this } \\
\text { publication) }\end{array}$ \\
\hline
\end{tabular}

\section{ADDITIONAL OPTIONS OF GHG MITIGATION}

\section{Crop rotation in wetland rice field}

As we aware, in Indonesia wetland rice field is the major source of GHG emission from agricultural sector. The GHG emitted from wetland rice field actually is not only methane gas but also other important $\mathrm{GHG}$, i.e. $\mathrm{CO}_{2}$ and $\mathrm{N}_{2} \mathrm{O}$. So far, the study on $\mathrm{CO}_{2}$ emission from wetland rice field in Indonesia is very scare, this is also the same to some degree for $\mathrm{N}_{2} \mathrm{O}$. It is also well known that in a good irrigation management area, crop rotation between wetland rice with other upland crops is frequently done by farmers. This is not only for the economic reason to get more benefit but also to control pest and deceases. Other reason is because irrigation water for the second consecutive wetland rice is not sufficient. So, this situation could be more encouraged by government by preparing better accessibility for farmers to agricultural inputs such as seed of upland crops, fertilizers, pesticides as well as with guaranty for a better price for their agricultural yield. In the Table 4, it had been shown clearly, a tremendous amount of methane emission was reduced when the wetland rice field is cultivated with upland crops. Many cases, the source of methane emission site was converted to a sink of methane gas site. It is important also to note that the amount of methane was sink in this agricultural system was high. However, this proposed option of GHG mitigation should be evaluated intensively in the future.

\section{Application of System of Rice Intensification (SRI)}

This system of rice cultivation developed 25 year ago in Madagascar by France pries Laulanie. The basic concept of SRI characterized by using young rice seedling (8-12 days old), a single seedling per hill, wider planting distance $(30 \mathrm{~cm} \times 30 \mathrm{~cm})$ and intermittent irrigation water. In addition to the above characteristics of SRI, provision of organic matter to the soil in form of compost has been recommended (Sato, 2005). This system of rice cultivation have been tested very intensively since 2002 till 2005 in 8 provinces in Eastern part of Indonesia. As much as 12.133 field trials and area of 9.429 ha had been used in this intensive on farm trials. The remarkable results were obtained i.e. an average $78 \%$ rice yield increase, $50 \%$ less inorganic fertilizers used, $40 \%$ less water consumed and $20 \%$ less input required (Sato and Uphoff, 2007). This is in line with the results of experiment done in 8 countries carried out by a variety of institutions encompassing almost 6.000 trials. The results showed that; yield increased $(\mathrm{t} / \mathrm{ha})$ $52 \%$ (range $21-105 \%$ ); reduction in water use $44 \%$ (24$60 \%)$; reduction of cost of production $25 \%(2.2-56 \% 0$; increase of the net income per ha $128 \%$ (59-412\%) (Uphoff, 2007). Currently, this system of rice cultivation are being in 30 rice producing countries. In Indonesia, this rice cultivation has just got political support from the government. President of Republic of Indonesia has given his strong support to implement this System of Rice Intensification (SRI) through Indonesia.

In relation to GHG emission to SRI, it is very obvious that SRI system more likely to emit less GHG since this system use intermittent irrigation water, less inorganic fertilizers, two of the basic options of GHG mitigation studied. In addition to these, SRI increased rice yield in average of $78 \%$. This is the most encouraging factor for farmer to implement this option. Mostly farmers are attracted to use new option when the really got a real benefit such as increase of rice yield. Other encouraging factors are less water requirements (40\%), less input (20\%) and less seed needed. These all are the most important factors for farmer to adopt this option. Moreover, as national politics, the Government of Indonesia has strongly support this alternative of rice cultivation. However, none or at the very early stage of the study of GHG emission are 
being done in SRI system. Therefore, an intensive study of GHG emission as well as in the other microbiological aspects of SRI are urgently needed in the near future.

In relation to this, ICAS Ibaraki University lead by Prof. Dr H. Ohta, has prepared a three-year collaborative study proposal, not only for the field experiments but also for laboratory and greenhouse experiments. The experiments will be done in Japan as well as in Indonesia.

\section{POSSIBLE CONTRIBUTION OF (INDONESIAN) FARMER IN REDUCTION OF GHG EMISSION FROM WETLAND RICE FIELD}

As it has been discussed in the introduction, every country in the world have to participate by any way to implement any effort to reduce GHG emission of every sector. Actually, as it has stated by leaders of states they would like to take any action to reduce GHG emission as they can. For Indonesian situation, the same as in other countries, in agricultural sector no any single mitigation is being implemented so far. This is also the case in China, India, Thailand, Philippine, Vietnam and in other countries. The contribution of agricultural sector in GHG emission in Indonesia is very big, it reach as much as $26 \%$ of the Total GHG emission in the country. Taking into account that the available mitigation option can reduce GHG emission by $50 \%$, this means that as much as $13 \%$ of the Total GHG emission in Indonesia can be reduced. If the country like China, India and Thailand take the same action, the considerable high percentage of Total World GHG emission can be reduced. However, the main problem is how to encourage the participation of the farmer to implement the mitigation option.

We here again would like to stress that the farmers will participate in implementing the options of GHG mitigation when the farmers get a real benefit from the options such as increase of rice yield, reduce fertilizer consumption, consume less irrigation water and need less input. These benefits benefit are only provided by SRI system of rice cultivation. However, this suggested option should be intensively evaluated.

In Indonesia situation, there is a strong power to implement GHG mitigation option through SRI, since SRI has got political will of the Indonesia Government. However, the implementation of SRI as an alternative option of GHG mitigation should be back-up by intensive scientific study.

\section{CONCLUSIONS}

In rice producing countries such as Indonesia, farmers can contribute significantly in reducing GHG emission. Some of the GHG mitigation options are available but none of these option is being implemented by farmer. Crop rotation in wetland rice field between wetland rice cultivation with upland crops is one of additional option proposed. The other GHG mitigation option that probably more attractive to farmer to implement is SRI. Through Sri implementation, the farmers get many direct benefit. Moreover, in Indonesia, SRI has got a strong support from government. However, the study of the usefulness of SRI as option on GHG mitigation should be studied intensively.

\section{ACKNOWLEDGEMENTS}

I would like to thank the management of the Institute for Global Change Adaptation Science (ICAS) Ibaraki University particularly the President of Ibaraki University Prof. Dr Ryuzaburo Kikuchi and the Director of ICAS Prof. Dr Nabuo Mimura who appointed me as one of the Guest Professor at ICAS Program at Ibaraki University. Special thank is also directed to Prof. Dr Hiroyuki Ohta, who create and maintain an excellent atmosphere of collaboration at ICAS. Thanks are also directed to the Rector of Bogor Agricultural University (IPB) and the Dean of the Faculty of Agriculture IPB who strongly support my participation as Visiting Professor at ICAS Program of Ibaraki University, Japan

\section{REFERENCES}

Aulakh, M. S., Bodenbender, J., Wassmann, R. and Rennenberg, H. 2000. Methane transport capacity of rice plants. II. Variations among different rice cultivars and relationship with morphological characteristics. Nutrient Cycling in Agroecosystems, 58:367-375.

Bachelet, D. and H.U. Neue. 1993. Methane emissions from wetland rice areas of Asia. Chemosphere, 26:219-237.

Duxbury, J. M., A. R. Mosier. 1997. Status and issues concerning agricultural emissions of greenhouse gases. In Kaiser, H. M., and T. E. Drennen (Eds). Agricultural Dimensions of Global Climate Change. CRC Press LLC. p229-258.

Husin, Y. A. 1994. Methane Flux from Indonesian Wetland Rice: The Effects of Water Management and Rice Variety. A Dissertation. Post Graduate Program, Bogor Agricultural University. pp 201.

Husin, Y. A., Murdiyarso, D., Khalil, M. A. K., Rasmussen, R. A., Shearer, M. J., Sabiham, S., Sunar, A., Adijuwana, H. 1995. Methane flux from Indonesian wetland rice: The effects of water management and rice variety. Chemosphere, 31:31533180 .

Chidthaisong, A. 2006. Greenhouse gas study in Thailand agricultural sector: Research progress and future needs. MAGE NIAES Workshop Tsukuba, Japan 1314 December 2006.

Inubushi, K., Sugii, H., Watanabe, I., Wassmann, R. 2002. Evaluation of methane oxidation in rice plant-soil system. Nutrient Cycling in Agroecosystem, 64: 7177.

Inubushi, K. and Yagi, K. 2006. Research activities on greenhouse gas emissions from agricultural fields in 
Japan. MAGE NIAES Workshop Tsukuba, Japan 13-14 December 2006.

Iswandi, A., Suprihati, Tasnim, M., Megasari, N. K., Yagi, K. and Inubushi, K. 2007. The dynamics of $\mathrm{CH}_{4}$ and $\mathrm{N}_{2} \mathrm{O}$ in agricultural land in West Java, Indonesia with a special focus on microbiological aspects and risk management for agro-ecosystems in Asia (2004-2006). Final Report. Collaboration between Bogor Agricultural University (IPB) Indonesia with Faculty of Horticultura Chiba University, Matsudo, Japan and NIAES, Tsukuba, Japan.

Kumaraswamy, S., Rath, A. K., Ramakrishnan, B., N. Sethunathan, N. 2000. Wetland rice soils as sources and sinks of methane: a review and prospects for research. Biol. Fertil. Soils, 31:449-461.

Mathews, E., I. Fung and J. Lerner. 1991. Methane emissions from rice cultivation: geographic and seasonal distribution of cultivated areas and emissions. Global Biogeochem. Cycles, 5:3-24.

Rath, A. K., Mohanty, S. R., Mishra, S., Kumaraswamy, S., Ramakrishnan, B., Sethunathan, N. 1999. Methane production in un-amanded and rice straw-amanded soil at different moisture levels. Biol. Fertil. Soils, 28:145-149.

Sato, S. 2005. 3 years experiences of SRI (System of Rice Intensification) under SSIMP-DISIMP in Eastern Indonesia. Paper presented at Workshop on Integrated Citarum Water Management Project. 4 - 5 July 2005. Jakarta (JBIC ODA Loan IP-509).

Sato, S. and Uphoff, N. 2007. A review of on-farm evaluations of system of rice intensification methods in Eastern Indonesia. CAB Reviewed: Perspectives in Agriculture, Veterinary Science, Nutrition and natural Resources 2007. 2 No. 054 CABI Publishing 2007 (Online ISSN 1749-8848).

Setyanto, P., Rosenani, A. B., Boer, R., Fauziah, C. I., and Khanif, M. J. 2004. The effect of rice cultivars on methane emission from irrigated rice field. Indonesian Journal of Agricultural Science, 5:20-31.

Shearer, M.J and M.A.K. Khalil. 2000. Rice agriculture: emissions. In M.A.K. Khalil (Ed). Atmospheric Methane its Role in The Global Environment.
Springer-Verlag Berlin Heidelberg. New York. p. 170-189.

Shin, Y. K. and Lee, Y. S. 2006. Estimation and mitigation of greenhouse gases (GHGs) from Korean Agriculture. MAGE NIAES Workshop Tsukuba, Japan 13-14 December 2006.Sigh, S., Kumar, S. and Jain, M. C. 1997. Methane emission from two Indian soils planted with different rice cultivars. Biol Fertil. Soils, 25:285-289.

Suprihati. 2007. Dinamika populasi mikroba dan fluks metana (CH4) serta nitrous oksida (N2O) pada tanah sawah: Pengaruh pengelolaan air, bahan organic dan pupuk nitrogen. Disertasi Sekolah Pasca Sarjana IPB Bogor Indonesia (Unpublished).

Uphoff, N. 2007. The system of rice intensification: Using alternative cultural practices to crease rice production and profitability from existing yield potentials. International Rice Commission Newsletter No.55 Food and Agriculture Organization, Rome.

UNFCCC. 2006. Greenhouse gas data report points to rising emission trends. Bonn, 30 October 2006). The secretariat of the United Nations

Wang, B. and Adachi, K. 1999. Methane production in a flooded soil in response to elevated atmospheric carbon dioxide concentrations. Biol. Fertil. Soils, 29:218-220.

Wang, B. and Adachi, K. 2000. Differences among rice cultivars in root exudation, methane oxidation, and populations of methanogenic and methanotrophic bacteria in relation to methane emission. Nutrient Cycling in Agroecosystems, 58:349-356.

Wang, B., Xu, Y., Wang, Z., Li, Z., Ding, Y., and Guo, Y. 1999. Methane production potentials of twentyeight rice soils in China. Biol. Fertil. Soils, 29:74-80.

Wassmann, R. and Aulakh, M. S. 2000. The role of rice plants in regulating mechanisms of methane missions. Biol. Fertil. Soils, 31:20-29.

Wassmann, R. 2006. Greenhouse gas emission from rice fields: What do we know and where should we head for? MAGE NIAES Workshop Tsukuba, Japan 1314 December 2006. 